\title{
Particles, Prefixes, and Suffixes
}

\subsection{Possessive Particles}

In addition to the construct chain (discussed in 4.3), Hasidic Hebrew has two particles, the characteristically post-biblical של 'of' and its Aramaic counterpart $-ד$, that serve to designate possessive and adjectival relationships between nouns. In contrast to many other elements of Hasidic Hebrew grammar in which biblical and post-biblical variants are employed interchangeably, these possessive particles are often restricted to specific semantic and syntactic contexts, discussed below.

\section{של 12.1.1}

The typically rabbinic possessive particle של 'of' is sometimes employed in Hasidic Hebrew instead of the construct chain. In some cases של is used interchangeably with the construct chain, but often its appearance is restricted to certain settings such as set expressions and noun phrases containing attributive adjectives or proleptic suffixes. Moreover, in general של is used somewhat less frequently and productively in Hasidic Hebrew than the construct chain. This is noteworthy for two main reasons. Firstly, as של is a characteristic marker of Rabbinic Hebrew (Pérez Fernández 1999: 32; Bendavid 1971: 462, 469), the fact that it is not the most prominent way of expressing possession in Hasidic Hebrew indicates that (in contrast to the Maskilic-based scholarly assumption) in this respect, as in many others, the language of the tales is not solely or primarily rooted in the rabbinic model. Secondly, the authors' preference for the construct chain indicates that in this regard they were not overly influenced by their native Yiddish, considering that the Yiddish possessive particle פון 'of' bears a much closer syntactic resemblance to של than to the construct chain.

The various patterns surrounding the use of של של are examined below.

\subsubsection{Interchangeable with Construct Chain}

In some cases של is employed in identical syntactic contexts to the construct chain, i.e. indicating a possessive or adjectival relationship between two nouns, which may be either definite or indefinite, as below. This interchangeable use of the construct chain and של is underscored by the fact that a single author may employ the same two nouns in both constructions within the same paragraph, as the final example illustrates.

(C) LILY KAHN, 2015 | DOI: 10.1163/9789004281622_013 
- לשל רלת של החדר 'the door of the room' (Berger 1910b: 108)

- לשלחן של רבנו הקדוש החדר 'to the table of our holy Rebbe' (Gemen 1914: 77)

- הכוס של היין 'the cup of wine' (Brandwein 1912: 47)

- מנורות של כסף 'silver candelabras' (Michelsohn 1912:63)

- בשלשלאות של ברזל שסף'with iron chains' (Ehrmann 1905:45b)

- התמונות של הגראר ברזל 'the pictures of the count' (Heilmann 1902: 105)

- העיר של הכלה של 'the bride's town' (Shenkel 1883, pt. 1:11)

- 'in a Sabbath shtreimel' (M. Walden 1913, pt. 3:8)

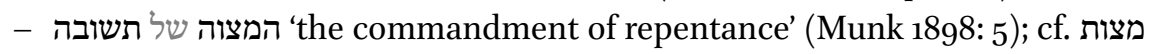
'the commandment of repentance' (Munk 1898: 5)

This phenomenon has a parallel in Rabbinic Hebrew, in which the construct chain and particle של often overlap in usage (Pérez Fernández 1999: 32). Howשל ever, as mentioned above Hasidic Hebrew makes much more sparing use of than its rabbinic antecedent. There is some variation in this respect between individual authors; for example, Bromberg and Shenkel employ של more frequently than Kaidaner, who avoids it almost entirely; nevertheless, the tales are relatively uniform in that no author uses של more often than the construct chain.

\subsubsection{In Set Phrases}

Although של is sometimes employed productively in contexts indistinguishable from those in which the construct chain is found, it often appears as part of a set phrase that is well known from rabbinic literature. Examples of this are the phrases shown in the following examples, all of which are attested in rabbinic and medieval texts such as the Babylonian Talmud, midrashim, Rashi's commentaries, etc. The relative frequency of cases in which של appears in set phrases constitutes further evidence of the Hasidic Hebrew authors' overall preference for the construct chain as a productive method of expressing nominal possession.

- ב"ד של מעלה 'the Heavenly Court' (Shenkel 1903b: 8)

- אחרון של פסח 'the last night of Passover' (Bromberg 1899:38)

- שביעי של פסח 'the seventh day of Passover' (Sofer 1904:1)

- ישיבה של מעלה שליה מ.... 'heavenly academy' (Brill 1909: 81)

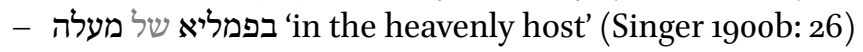

- מלך של חסדר מלד 'king of mercy' (A. Walden 186o?: 40b) 


\subsubsection{With Proleptic Suffix}

In at least half of the cases in which של appears in the Hasidic Hebrew tales, it is employed in conjunction with a third person proleptic possessive suffix. The suffix is typically $3 \mathrm{~ms}$, but may occasionally be 3 fs or $3 \mathrm{mp}$. The construction is typically employed in phrases where the possessor is definite, as in the following examples.

\section{With 3ms Suffix}

- נכדו של הבעש"ט 'the grandson of the Ba’al Shem Tov' (Zak 1912:153)

- 'the daughter of this taxman' (Sobelman 1909/10, pts. 1-2: 4)

- שוויו של הדבש של 'the worth of the honey' (Sofer 1904:38)

- מכיסו של הבגד של של 'from the pocket of the garment' (Berger 1907:115)

- זנבו של הדג 'the tail of the fish' (Brandwein 1912: 20)

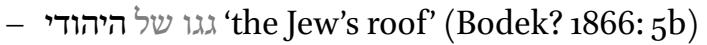

- למקום מנוחתו של החסיד הנ"ל 'to the resting place of that Hasid' (Brill 1909: 81)

- ואמו של אביו 'and his father's mother' (N. Duner 1912: 27)

- 'the power of the Rebbe' (Ehrmann 1905: 85b)

- to the house of the informer' (Heilmann 1902: 199)

- אביו של המהר״ל מפראג 'the father of the Maharal of Prague' (Jacob Isaac ben Asher of Przysucha 1908: 111)

- תמיס 'his father's brother-in-law' (Michelsohn 1910c: 47)

- תלמידו של המגיד ממעזריטש'the student of the Maggid of Mezeritch' (Rakats 1912, pt. 1: 14ii ${ }^{1}$ )

\section{With 3 fs Suffix}

- לבה של היתומה 'the heart of the orphan girl' (Bodek 1866:1)

- זיוויגה של בתך 'your daughter's match' (Bodek? 1866: 3a)

\section{With 3cp Suffix}

- עונותיהם של ישראל 'the sins of Israel' (Munk 1898: 16)

- אידיהם פסח של הנוצרים 'the Christians' holiday Easter' (Rodkinsohn 1865:18)

This construction most likely derives directly from Rabbinic Hebrew, in which it is a prominent feature (Pérez Fernández 1999: 32). However, the Hasidic

1 Two consecutive pages in this text are both numbered 14. 
Hebrew authors deviate somewhat from rabbinic precedent in that this proleptic construction is for them the most common vehicle for של, while in rabbinic literature the particle is widely attested in many other settings as well.

In addition, this construction is sometimes found in conjunction with a possessor that is a common noun and lacks a definite article, as in the following examples. Many of the phrases in question appear in rabbinic and medieval literature, and the authors may therefore simply have borrowed them as set phrases from these sources, but not all such forms are clearly ascribable to this influence (e.g. the phrase in the last example seems to lack precedent).

- לשתף בצערן של תלמידי חכמים 'to sympathize with the woes of Torah scholars' (Bodek 1865a: 4)

- הפרנסתו של איש יהודי 'the livelihood of a Jewish man' (Breitstein 1914:51)

- זכרונו של אדם 'the memory of a man' (Singer 19oob: 28)

- כוחה של אשה צנועה 'the power of a modest woman' (Ehrmann 1911: 20a)

- קברו של איש אחר 'the grave of another man' (Berger 1910c: 12)

In some such cases the meaning of the possessor is definite even though it is not marked as such, e.g.:

- עולה של תורה 'the yoke of Torah' (Bodek 1865a: 29)

\subsubsection{With Attributive Adjectives}

Another relatively common Hasidic Hebrew use of של is in possessive constructions containing attributive adjectives. Indeed in such contexts the authors prefer the particle to the construct chain, which appears only rarely with attributive adjectives (see 4.3.2.10). The adjectives in these possessive constructions usually modify the first noun rather than the second, but occasionally they may modify the second noun as well. These possibilities are illustrated below. The authors' preference for של instead of the construct chain in phrases containing attributive adjectives suggests that, uncharacteristically, in such cases they were more at ease with the particle. This may be due to confusion caused by their tendency to use adjectives as members of construct chains.

- מעשה גדולה ונוראה של הרב אור העולם 'a great and awesome story of the Rebbe, light of the world' (Shenkel 1903b: 7)

- Maimonides meant by this the [...]"הרמב"ם כוון בזה לסוד האמתי של הקטורת (S) real secret of the incense' (Bromberg 1899:48) 
- תלמיד מובהק של הרב הקדוש 'an outstanding student of the holy Rebbe' (Rodkinsohn 1864b: 17)

- 'the deceased father of that orphan' (Zak 1912: 9)

- תלמיד מובהק של המגיד הקדוש ז״' 'an outstanding student of the holy Maggid of blessed memory' (Bodek 1865a: 25)

- 'to the hallowed house of the holy Rebbe' (Rakats 1912, pt. 1: 42)

\subsubsection{With Pronominal Suffixes}

Just as Hasidic Hebrew may express the possessive or modifying relationship between two nouns by either the construct chain or a possessive particle, so it may express the possessive relationship between a noun and a personal pronoun either by means of a possessive suffix attached to the noun (see 6.2.1) or by the particle של with a pronominal suffix following the noun. The two constructions are used with similar frequency. The authors' motivations for selecting של with a pronominal suffix instead of a suffixed noun on any given occasion are not always clear. In many cases של with a pronominal suffix often seems to be used in conjunction with post-biblical nouns and Yiddish loanwords that the authors might have perceived as awkward with a possessive suffix. This trend is illustrated in the following examples, which contain nouns denoting characteristically rabbinic and medieval or early modern concepts.

- הרבי שלך 'your Rebbe' (Ehrmann 1905: 85b)

- הכתבים שליר 'my writings' (Hirsch 1900: 32)

- להעגלון שלי' 'to my carriage-driver' (Kaidaner 1875: 27b)

- 'his bar mitzvah' (Heilmann 1902:2)

- התפילין שלנו שלו 'our phylacteries' (Rodkinsohn 1864b: 5)

Nevertheless, של with pronominal suffixes is additionally found in conjunction with words that are not specifically post-biblical, e.g.:

- העגלה שלי 'my wagon' (Jacob Isaac ben Asher of Przysucha 1908: 51)

- הידים שלה שלי' 'my hands' (Chikernik 19o3b: 6)

- ויכנוס לחדר שלו 'And he entered his room' (Rodkinsohn 1865: 13)

In some such cases it is nevertheless possible that the nouns in question struck the authors as non-biblical because of their frequent use in post-biblical sources and in Yiddish, and therefore they did not naturally combine them 
with a more characteristically biblical possessive suffix. However, this may not be applicable in all cases: for example, in the phrase shown in the final example below it does not seem particularly likely that the authors would have perceived the word חדר 'room' as post-biblical, given that it is used with an identical sense in the Hebrew Bible (Even-Shoshan 2003: 525).

Usually the possessive particle is used in conjunction with definite nouns. However, rarely it is found with an indefinite head noun, as below.

- שני עבדים שלה 'two slaves of hers' (Hirsch 1900: 73)

- ולקח תכשיטין שלה שלה שלה 'And he took jewels of hers' (Ehrmann 1905:57a)

- להוציא את העני ועגלה שלו 'to remove the pauper and his wagon' (Breitstein 1914: 26)

- תנו לי עגלה שלכם 'Give me your wagon’ (Sobelman 1909/10, pts. 1-2: 8)

This practice has precedent in Rabbinic Hebrew (see e.g. Sharvit 2004: 74 for examples). It may be reinforced by the fact that in Yiddish nouns in the standard possessive adjective construction do not take the definite article (Jacobs 2005: 183).

\subsection{2}

In addition to the post-Biblical Hebrew possessive particle של, the Hasidic Hebrew authors make use of its Aramaic equivalent, -ד. However, they do not seem to have regarded this Aramaic particle as interchangeable with the construct chain or של: instead of employing it to indicate possessive relationships, they typically use it to convey geographic or, somewhat less frequently, temporal ones. Interestingly, in these settings - ד is used extremely systematically, to the almost complete exclusion of the construct chain and של

\subsubsection{Geographic Sense}

The particle - ד is most commonly used to indicate geographic relationships. In such contexts it usually links a common noun with a following proper one; the common noun generally denotes an individual, event, or institution originating from or based in a particular geographic location while the proper noun denotes the location in question. In some cases the particle is instead קהילה crefixed to a common noun with geographic reference such as 'city' or 'community'; this itself may be unaccompanied, followed by the place name, or bear a possessive suffix. Occasionally, the second constituent may be an adverb of place rather than a noun. These possibilities are all illustrated below. The origins of this construction are not completely clear, though it may be based 
on analogy with the well-known Hebrew and Yiddish designation for Vilnius, 'ירושלים דליטא 'Jerusalem of Lithuania'.

- יום השוק דבאלטע 'the market day of Balta' (Rodkinsohn 1865:37)

- הרב החדש דפינסק 'the new rabbi of Pinsk' (Teomim Fraenkel 1911a: 10)

- בביבליעק דעיר מלוכה וויען 'in the library of the capital city Vienna' (Bodek 1866: 5)

- לבית הפרנס דעיר 'to the house of the community leader of [the] town' (Bodek 1866: 7)

- 'and also the rabbi of our community' (Kaidaner 1875:26b)

- בבית הכנסת דשם 'in the local synagogue (lit: the synagogue of there)' (Shenkel 1903b: 24)

- 'the local rabbi (lit: rabbi of there)' (Ehrmann 1903:15a; Singer 19oob: 3)

- והנהר דפה עלה 'And the local river (lit: the river of here) rose' (Landau 1892: 18)

- להרופאים דשם 'to the doctors of that place (lit: there)' (Moses Leib of Sasov 1903: 21a)

- מרב דפה 'the rabbi of this place (lit: here)' (Michelsohn 1912: 6)

- מהרב דקהלתנו 'from the rabbi of our community' (A. Walden 1860?: 12a)

- א' מהמנגדים דוויטעבסק 'one of the opponents [of Hasidism] of Vitebsk' (Heilmann 1902:197)

- פחד הערלים דשם 'fear of the local gentiles (lit: gentiles of there)' (Rosenthal 1909:44)

- בשני עברי נהר דשם 'on both sides of [the] local river (lit: river of there)' (Rakats 1912, pt. 1: 9)

\subsubsection{Temporal Sense}

The particle - 7 can also be used in a temporal sense. This usage is less frequent than the geographic sense discussed above but is still not uncommon. In such cases - - generally appears between two common nouns, with the first noun indicating an event that takes place at a set time, e.g. סעודת שחרית 'morning

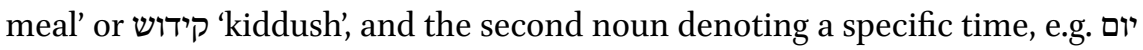
' ליל שבת Friday evening'. More rarely this pattern may be reversed, with the first noun designating the time and the second noun referring to the event. These patterns can be seen in the following examples.

- קידוש דליל שבת 'Friday night Kiddush' (Bromberg 1899:34)

- יום ג' דחול המועד פסח 'The third day of the intermediate days of Passover' (Gemen 1914: 54) 
- ביום א' דסליחות' 'on the first day of the Selichot prayers' (Stamm 1905: 15)

- ביום ב'דשבועות 'on the second day of Shavuot' (M. Walden 1912: 33)

The precise derivation of this temporal usage is more obscure than that of the geographic one, save that in a general sense it is most likely traceable to the frequent appearance of $-\tau$ in the Babylonian Talmud and later Aramaic writings. Moreover, the fact that the Hasidic Hebrew authors systematically employ $-T$ in these two specific contexts while avoiding it almost completely in others is striking and cannot clearly be ascribed to any particular motivation or linguistic influence. This phenomenon lends further support to the proposal that many Hasidic Hebrew non-standard usages are not indiscriminate but rather can be considered systematic internal developments.

\subsubsection{Exceptions}

There are rare exceptions to the above patterns whereby $-T$ is found in contexts that appear interchangeable with those in which the construct chain and של-T ise more commonly employed. The following is an example of this very marginal phenomenon.

- וכמעשה דהשטן עם איוב 'and like the story of the adversary with Job' (Ehrmann 1903: 7a)

The authors' motivation for the occasional selection of $-ד$ in such settings when they typically reserve it for geographical and temporal contexts is not clear, though it may suggest that the particle's role as a marker of geographical and temporal relationships, though largely regular, had not yet been entirely crystallized during the period of the tales' composition.

\section{אין}

The particle אין 'not'; 'there isn't'; 'there aren't' is commonly used in Hasidic Hebrew both as a negative existential particle and as a negator in verbless and participial clauses. The particle may take pronominal suffixes, as shown in the following table. Where multiple variants of a single form are listed (e.g. the ics (אינני and (איני , they are used interchangeably unless otherwise indicated in the discussion below. 


\begin{tabular}{|c|c|c|c|}
\hline \multicolumn{2}{|c|}{ Plural } & \multicolumn{2}{|l|}{ Singular } \\
\hline אינם & $1 \mathrm{cp}$ & אינני, איני, אינו & $1 \mathrm{cs}$ \\
\hline אינכם & $2 \mathrm{mp}$ & אינך, אינכם, אינו & $2 \mathrm{~ms}$ \\
\hline- & $2 \mathrm{fp}$ & - & $2 \mathrm{fs}$ \\
\hline אינם, אינן & $3 \mathrm{mp}$ & אינו, איני & $3 \mathrm{~ms}$ \\
\hline- & $3 \mathrm{fp}$ & אינה, איננה & $3^{\mathrm{fs}}$ \\
\hline
\end{tabular}

The suffixed forms of generally conform to biblical and/or rabbinic precedent regarding morphology but exhibit a few noteworthy differences from the canonical forms of Hebrew regarding person and number.

Firstly, as in the case of the personal pronouns, the $2 p$ form can also serve as a polite $2 \mathrm{~s}$ form. (No examples of feminine addressees with אין appear in the tale corpus.)

- ואמר לו ר' פייוויל האתם אינכם מכיר אותם (And Reb Faivel said to him, "Don't you know them?"' (Munk 1898: 50)

Secondly, the role of the forms אינם and, which are 3ms and 3mp in other forms of Hebrew, has been extended so that אינם also serves as a 2ms and 1cs form, while also serves as a 1cp form, e.g.:

\section{אינו}

- אני אינו לוקח רק זהב אחד מחנות 'I don't take [anything] except one gold [piece] from a shop' (Kaidaner 1875:33b)

- And he claimed that I don't need the kaddish so much' (Zak 1912: 9)

- אני אינו יכול להועילך 'I can't be of benefit to you' (J. Duner 1899: 16)

- הנה גם אתה אינו רחוק בודאי מטבעו לידו 'You see, you are also certainly not far away from his nature' (Kaidaner 1875: 46a)

- הלא אתה אינו שוטה 'Of course, you're not a fool' (Munk 1898:65)

אינם אי

- אנחנו אינם יודעים 'We don't know' (Rosenthal 1909:14)

- ואנחנו אינם יראים 'And we aren't afraid' (Chikernik 1902:32) 
Conversely, the traditionally 1cs form אינו can also serve as a 3ms form:

- והצפור הלז איני מבשר טוב כידוע 'And that bird does not bode well, as is known' (Ehrmann 1903: 49b)

A similar, though not identical, phenomenon is found in medieval and early modern responsa literature, in which gender and/or number discord is attested in negative constructions with suffixed forms of אין (Betzer 2001: 91), and, as in many other instances, it is likely that the Hasidic Hebrew convention was inspired or reinforced to some degree by the existences of this related practice. Moreover, like many other non-standard aspects of Hasidic Hebrew morphosyntax, this phenomenon is most likely directly attributable at least in part to phonological factors: the forms אינו wינו would most likely have been pronounced identically as [ejnə] or [ajne] in the authors' Ashkenazi Hebrew, which could have led to confusion between the written forms.

\section{את}

The accusative marker את is a relatively common feature of Hasidic Hebrew, though its forms and uses do not always correspond precisely to other forms of the language. Noteworthy morphological and syntactic aspects of the particle are discussed below.

\subsubsection{Morphology}

12.3.1.1 With Pronominal Suffixes

The accusative marker את is frequently attested with pronominal suffixes in the tales. The suffixed forms of the particle are as follows:

\begin{tabular}{|c|c|c|c|}
\hline \multicolumn{2}{|c|}{ Plural } & \multicolumn{2}{|l|}{ Singular } \\
\hline אותנו & $1 c p$ & אותי & $1 \mathrm{cs}$ \\
\hline אתכם & $2 c p$ & אותך, אתכם & $2 \mathrm{~ms}$ \\
\hline \multirow{3}{*}{ אותם, אותן } & & אותך & $2 \mathrm{fs}$ \\
\hline & $3 c p$ & אותו & $3 \mathrm{~ms}$ \\
\hline & & אותה & $3^{f s}$ \\
\hline
\end{tabular}

Remarks on noteworthy aspects of individual forms are given below. 


\subsection{Spelling}

The $1 \mathrm{cs}, 3 \mathrm{~ms}$, and 1cp forms are consistently spelt plene. The fact that the 1 present in the other forms is missing in the $2 \mathrm{cp}$ indicates that the Hasidic authors followed the standard Hebrew convention whereby the holem of the other forms is replaced by segol (although due to the lack of pointing, it is difficult to be completely certain that lack of i should definitely be interpreted as indication of a segol).

12.3.1.1.2 2fs Form

The 2 fs form is only very infrequently attested; a rare example is shown below. Because the texts are unvocalized it is not clear whether the authors systematically distinguished between the $2 \mathrm{~ms}$ and $2 \mathrm{fs}$ variants (particularly given their propensity to use traditionally $2 \mathrm{~m}$ subject pronouns with 2 f reference; see 6.1.1.2 and 6.1.1.3).

And his mother wanted to give him food [...] and he said [...] "I will support you from now on"' (Sofer 1904: 7)

\subsection{2cp/2ms Form אתכם}

The form אתכם is common in gender; an example with a feminine plural subject is shown below:

A And there were two women [... and he said "[...] I will free you"' (Rodkinsohn 1865: 14)

Moreover, it can serve as a polite $2 \mathrm{~ms}$ form, e.g.:

- The holy Rebbe said, "Do you know me?" And he said, "I know that you are a Rebbe"' (Sofer 1904: 35)

- The old man answered him, "My father hit me." "Why did he hit you?"' (Sobelman 1909/10, pts. 1-2: 38 )

\subsection{3cp Forms}

As in the case of the independent personal pronouns (discussed in 6.1.1.8), Hasidic Hebrew does not distinguish masculine and feminine gender in the third person plural object pronouns. Instead, it has two interchangeable $3 \mathrm{cp}$ variants. However, אותם is more frequently attested than אותן, as illustrated below. 
אותם

- לישיב אותם 'And he answered them' (Bodek 1865c: 1)

- לבלי לתלות אותם 'not to hang them' (Munk 1898: 22)

- תלמידי בעש"ט ביקשו אותו פ"א כי ילמוד אותם 'The students of the Ba’al Shem Tov asked him once to teach them' (Ehrmann 1903: 3b)

- כל הבהמות [...] והנכרי הנ"ל הכה אותם 'All the animals [...] and that non-Jew beat them' (Chikernik 1902: 11)

אותן

- פלאים אשר לא שמע אותן 'wonders which he had not heard' (Teomim Fraenkel 1911b:10)

- ומעלים אותן 'And they raise them up' (Menahem Mendel of Rimanov 1908: 22)

\subsubsection{Use}

\subsubsection{Distribution}

In many cases definite nouns in Hasidic Hebrew are preceded by the accusative particle את. This applies to nouns prefixed by the definite article and nouns with a possessive suffix. (There are no examples of proper nouns preceded by את in the tales.) These possibilities are illustrated below. In this respect Hasidic Hebrew follows the standard convention in Biblical and Rabbinic Hebrew (see Rabin 2000: 117).

\section{With Definite Article}

- לשכור את הקרעשטמא שלי הלזו 'To rent this inn of mine' (Teomim Fraenkel 1911b: 92)

- הלכה וחלבה את החזירה 'She went and milked the pig' (Ehrmann 1911:5b)

- ויצו הרב להעבד כנעני שלו לרתום את הסוסים 'And the rabbi ordered his nonJewish servant to bridle the horses' (Rodkinsohn 1865:1)

- והכניס את מקום נטיפת הגג אל תוך הבית 'And he brought in the place where the roof was leaking into the house' (Sobelman 1909/10, pts. 1-2: 36)

- והוא שלח לו בחזרה את הרצועה 'And he sent him back the strap' (Brandwein 1912:10)

- הייתי מוכרח לעזוב את מאכלי 'I was forced to leave my meal' (Hirsch 1900: 29)

- ולקח את הטלימיק שלו 'And he took his bag' (Baruch of Medzhybizh 1880:28)

- ולקח הרב את האופן 'And the Rebbe took the wheel' (N. Duner 1912:18)

- לקחת את העושר הרב הזה הת 'to take this great wealth' (Rosenthal 19o9:19) 
- ויקח הרב את הגביע 'And the Rebbe took the goblet' (Seuss 1890:5)

- וירא את הכסף המביע 'And he saw the silver' (Shenkel 1883, pt. 1:7)

- הלך הטמין את המעות 'He went and hid the money' (Greenwald 1899:56a)

- ויקח את הפישקעלע 'And he took the box' (Chikernik 1903b: 22)

\section{With Possessive Suffix}

- מיד פתח הינוקא קדישא את פיו 'The holy child immediately opened his mouth' (Zak 1912: 9)

- לעזוב את רבו 'to leave his Rebbe' (Singer 19oob: 24)

- לפתוח את פת רביו 'to open his mouth' (Bodek? 1866: 7b)

- לשמוע את דיבוריהם 'to hear their speech' (Jacob Isaac ben Asher of Przysucha 1908: $\left.5^{2}\right)$

However, the Hasidic Hebrew authors do not always employ את in conjunction with definite direct objects; indeed, they omit it somewhat more often than they insert it. Examples of this strong tendency to avoid את before objects preceded by the definite article and with possessive suffixes are shown below.

\section{With Definite Article}

- לאכול הבשר 'to eat the meat' (Gemen 1914:48)

- והגבהתי הכוס 'And I raised the cup' (Shalom of Koidanov 1882: 20)

- שוב הניח עוד הקויטל מידו 'Again he put down the note from his hand' (Teomim Fraenkel 1911b: 70)

- ולא היה יכול לסבול הפחד הגדול 'And he could not endure the great fear' (Bodek 1865a: 24)

- ולקח בידו הכסא 'And he took the chair in his hand' (Singer 19oob: 14)

- מכרו כל הלחם ביחס 'They sold all the bread' (Bodek? 1866: 23b)

- ולבש הבגדים 'And he put on the clothes' (Baruch of Medzhybizh 1880:2)

- And 'And he told him the truth' (Jacob Isaac ben Asher of Przysucha 1908: 99)

- ולקח המפתח אצלו 'And he took the key from him' (Rosenthal 1909:23)

- לכבה הנרות 'to extinguish the candles' (Seuss 1890:4)

- ותזכה לראות השכינה 'And you will merit seeing the Divine Presence' (Shenkel 1883, pt. 2: 29)

- בשביל מי בונים הפאלאטץ הגדול הזה 'For whom are they building this big palace?’ (Greenwald 1899:56a)

- לא סגרת הדלת 'You didn't close the door' (M. Walden 1913, pt. 3:13)

- האם אתה הבאת החבילה 'Did you bring the package?' (HaLevi 1909:53) 


\section{With Possessive Suffix}

- לחתוך ראשו 'to cut off its head' (Brandwein 1912:18)

- 'to give you his daughter' (Heilmann 1902: 120)

- והוא כשמוע דבריה פער פיו בשחוק גדול 'And when he heard her words, he opened his mouth in a great laugh' (Berger 1910a: 38 )

- אצל 'to leave his learning' (Singer 1900a, pt. 2:15)

- וישב אצל השלחן ואכל סעודתו בשמחה רבה 'And he sat at the table and ate his meal with great happiness' (Kaidaner 1875: 28a)

- והושיט ידו לקבל ברכת הפרידה 'And he stretched out his hand to receive the parting blessing' (Zak 1912: 12)

Direct object phrases lacking את are not restricted to specific semantic or syntactic settings; rather, the particle seems to be an optional element that can be inserted or omitted at random. The following two examples below illustrate this, as each one contains similar collocations appearing within the work of a single author both with and without את.

- ערל אחד נשא המעהרען 'A non-Jew had carried the carrots' (Michelsohn 1912: 84); cf. לאכול את המעהרין 'to eat the carrots' (Michelsohn 1912: 84-85)

- לזאת לקח השטערנטיכעל של אשתו 'Therefore he took his wife's headscarf' (Ehrmann 1905: 44b); cf. והה"ק פדה את השטערנ-טיעכל למעל 'And the holy Rebbe redeemed the headscarf' (Ehrmann 1905: 153a)

The authors' frequent omission of את likely stems at least in part from the fact that their native Yiddish does not possess such a particle, and that as such it was not natural for them to insert it. This may have been compounded by the widespread existence of a similar trend in a range of well-known Hebrew texts from the medieval period, including Rashi's commentaries, the Sefer Hasidim, Spanish-Provençal Hebrew prose (see Rosén 1995: 64-66 and Rabin 2000: 117) and translations from Arabic (Goshen-Gottstein 2006: 111). Rabin (2000: 117) proposes that this medieval convention is rooted in Paytanic Hebrew (which often omits את, as discussed in Rand 2006: 258-259), and that this in turn is based on Biblical Hebrew poetry, in which את is much less common than in biblical prose; alternatively, it is possible that the medieval authors tended to omit the particle for the same reason as their Hasidic descendants, precisely because it was lacking in their own native languages.

Finally, note that when there are two direct objects in a row, the first may be preceded by את while the second lacks it, e.g.: 
- לסבול את בכיותיה ותחנוניה 'to suffer her cries and begging' (Rosenthal 1909: 8)

\subsubsection{Preceding Indefinite Noun}

The particle את sometimes appears before an indefinite noun. This usage deviates from historical precedent, as in earlier forms of Hebrew את is typically restricted to definite direct object phrases. There are a few rare instances of this phenomenon in Biblical Hebrew, e.g. Num. 21:9 and 1Kings 12:31 (see Waltke and O'Connor 1990: 180-181 and Williams 2007: 168 for discussion). The construction seems to be slightly more common in Rabbinic Hebrew, particularly when the noun in question begins with a guttural consonant (Azar 1995: 6263). The biblical phenomenon is extremely marginal and is therefore unlikely to have inspired the Hasidic Hebrew construction. The rabbinic construction is perhaps more likely to have exerted some influence, though this is uncertain as it is not an extremely widespread feature of rabbinic literature and therefore it is unclear how much of an impression it would have made on the Hasidic Hebrew authors.

In some of these non-standard cases the authors may have selected because they perceived the constructions in question to be definite. For example, a few such nouns follow the noun כל 'every', which though grammatically indefinite may have been perceived by the authors as definite due to its meaning. This phenomenon is likewise attested in the Mishnah (Azar 1995: 63). Examples include the following:

- אנוכי אינני רואה כ"א כח האלקי המחיי את כל דבר הגשמי II don't see anything but the Godly power that keeps every physical thing alive' (Rodkinsohn 1864b: 39)

- והבעש"ט זל"ה בירך את כל איש ואיש (And the Ba'al Shem Tov of blessed memory blessed each and every man' (Ehrmann 1903: 3a)

Similarly, it is sometimes found preceding an indefinite noun that is followed by a suffixed possessive particle, which would likewise typically be understood as definite, e.g.:

- והראה לר' משה בידו שיקשור את עגלה שלו לעגלה של הדייטשיל 'And he indicated to Reb Moshe with his hand that he should tie his wagon to the wagon of the Maskil' (Sofer 1904: 23)

- איני רוצה אתכם ולא את מעות שלכם 'I don't want you or your money' (Sobelman 1909/10, pts. 1-2: 12) 
Conversely, in many cases the indefinite noun appears in syntactic contexts lacking any definite elements, wherein the authors' motivation for selecting the accusative particle is less clear, e.g.:

- ונרפא את אחרים 'And we will heal others' (Gemen 1914: 59)

- לקרוא את איש אחד ענר אברים 'to call one pauper' (Michelsohn 1912:36)

- מי הוא גנב את אבן יקרה 'Who it was [that] stole a precious stone' (Bodek? 1866: 16a)

- וישאל את איש אחד 'And he asked one man' (N. Duner 1912:2)

- לברך את ערל 'to bless a non-Jew' (Singer 19ooa, pt. 1:3)

- לשאת את תפילין ביום השבת אתרל לto carry phylacteries on the Sabbath day' (Breitstein 1914:60)

- האופה לקח את איש אחד לחתן 'The baker had taken a man for [his] son-in-law' (Rodkinsohn 1865:56)

- [לא היה יכול לסבול עוד את בני אדם 'He could not stand people any more' (Bromberg 1899: 41)

הנה

The particle הנה is an extremely common element of the tales. In this respect Hasidic Hebrew resembles its biblical antecedent, in which הנה plays a key role, in contrast to rabbinic literature, in which it does not feature (Segal 1927: 149). Its morphological, syntactic, and semantic properties are presented below.

\subsubsection{Morphology}

12.4.1.1 With Pronominal Suffixes

In Hasidic Hebrew הנה does not appear very frequently with pronominal suffixes. The attested suffixed forms are shown below.

\begin{tabular}{rlrl}
\hline \multicolumn{2}{c}{ Plural } & \multicolumn{2}{c}{ Singular } \\
\hline & $1 \mathrm{cp}$ & $1 \mathrm{cs}$ \\
- & $2 \mathrm{mp}$ & הנני & $2 \mathrm{~ms}$ \\
- & $2 \mathrm{fp}$ & - & $2 \mathrm{fs}$ \\
הני & $3 \mathrm{mp}$ & הנהו & $3 \mathrm{~ms}$ \\
- & $3 \mathrm{fp}$ & - & $3 \mathrm{fs}$ \\
\hline
\end{tabular}


The 3ms form הנהו, shown below, lacks precedent in the earlier canonical forms of Hebrew: in Biblical Hebrew the only 3ms form is (van der Merwe, Naudé, and Kroeze 1999: 329), while in Mishnaic Hebrew the particle הרי is used instead of הנה (Pérez Fernández 1999: 173). However, the variant הנהר is attested in the sixteenth- and eighteenth-century biblical commentaries of Moses Alshich and Chaim ibn Attar, which may be the direct source of the Hasidic Hebrew use of this form. The popularity of the form may have been reinforced by analogy with the identically spelt Aramaic term הנהו 'those', which is widespread in sources such as the Babylonian Talmud.

- הכתם טהור הנהו 'The stain is clean' (Sofer 1904:4)

- ויבט והנהו כתמונתו 'And he looked, and he was exactly according to his resemblance' (J. Duner 1899: 112)

- ולא הנהו מעולם 'And he has never been here' (Ehrmann 1903: 12a)

\subsubsection{Use}

The particle הנה is found in several syntactic and semantic contexts, detailed below.

\subsubsection{1 הנה in Direct Speech}

frequently appears at the very beginning of an utterance followed by a finite verb, as shown below. In these contexts it serves to draw attention to the following statement, with a translation value of 'you see' or 'it so happens that'. This usage corresponds to that of Biblical Hebrew, in which הנה is often found at the beginning of a direct utterance followed by a finite verb (see Zewi 1996 for details).

- אח"כ אמר לו הבעש"ט הנה ידעתי מבוקשך 'Afterwards the Ba'al Shem Tov said to him, "You see, I know [what] your request [is]"' (Rodkinsohn 1865: 6)

- 'And the holy Maggid said to them, "I will make a compromise between you"' (Gemen 1914: 64)

- הנה החילותי 'You see, I have begun' (Kaidaner 1875: 18a)

- הנה ידעתי כי איש חלש אתה 'I know that you are a weak man' (Seuss 1890: 5)

In some cases הנה appears at or near the beginning of an utterance with a pronominal suffix and directly followed by a qotel or non-verbal predicate. In such instances it usually marks the qotel as conveying present progressive or planned future action. Again, these usages all have precise counterparts in Biblical Hebrew (as discussed in Zewi 1996). 
- הנני רואה כי כן הוא 'I see that it is so' (Michelsohn 1910a: 44)

- הנני מבטיחך כי אעתיק אותו כראוי כ' 'I hereby promise you that I will copy it properly' (Rodkinsohn 1864b: 13)

- והנך רואה בעיניך שאני לבוש בגדי שבת 'And you see with your own eyes that I am wearing Sabbath clothes' (N. Duner 1899:77)

- וישאלו אותו מתי הלכת מביתך ללובלין. וישיב אותם הנני נוסע מלובלין אל ביתי 'And they asked him, "When did you leave your house for Lublin?" And he answered them, "[Actually], I am travelling from Lublin to my house"' (Bodek 1865c: 1)

- כד הנני מקיים כיבוד אב 'Thus I fulfil [the commandment of] honouring one’s father' (Rakats 1912, pt. 1: $14 \mathrm{i}^{2}$ )

Very rarely it serves as a nominal clause, e.g.:

- ויספר למו הדברים כאשר הנם 'And he told them the matters as they are' (Rakats 1912, pt. 1: 14iiं ${ }^{3}$ )

The suffixed particle is occasionally employed in conjunction with an independent pronoun. The use of the independent pronoun in addition to the suffix may be intended to draw attention to the subject through topicalization, though alternatively the authors may simply have used this particular construction because it was familiar to them from well-known biblical passages (such as Gen. 6:17, cited below), without any particular semantic considerations.

- אני הנני יודע 'I know’ (Ehrmann 1911: 43b)

- אני הנני מציע לי 'I suggest for myself' (Landau 1892:12)

- ואני הנני איש חלוש למאוד 'And I am a very weak man' (Jacob Isaac ben Asher of Przysucha 1908: 51)

- ואני הנני נותן את נפשי תחת נפשו 'And I will give my life in exchange for his life' (M. Walden 1912: 6o)

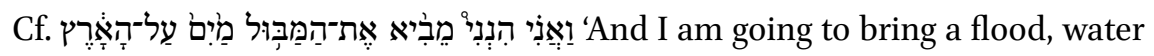
upon the land' (Gen. 6:17)

\subsubsection{2 (1) in Past Tense Settings}

הנה , In addition to its attestation in present and future direct speech contexts very commonly appears in past tense settings (usually in narrative but occa-

2 Two consecutive pages in this text are both numbered 14.

3 Two consecutive pages in this text are both numbered 14. 
sionally in direct speech) prefixed by the conjunction waw. In such cases it typically serves to introduce an element of vividness or immediacy, with a possible translation value of 'and it so happened', 'and there was' or 'when suddenly'. It may be followed by a variety of verbal forms with past tense force, including qotel and qatal with a past progressive sense and qațal with a preterite sense.

In such contexts והנה often follows the verb. ר.א.ר 'see', e.g.:

- וירא והנה ילד בתוך הדלי 'And he saw that there was a child inside the bucket' (Seuss 1890: 27)

- ופתאום ראה והנה צעיר לימים עמד לקראתו 'And suddenly he saw that a youth was standing near him' (Teomim Fraenkel 1911a: 32)

- וירא והנה צדיקים יושבים כשתילי זיתים סביב לשלחן המלך מלכו של עולם 'And he saw righteous men sitting like olive plants around the table of the King of the Universe' (M. Walden 1913, pt. 3: 26)

- ויהי כאשר הקיץ הרב משינתו וירא והנה הם נוסעים בדרך העולה לעיר באר 'And when the Rebbe awoke from his sleep, he saw that they were travelling on the road that goes up to the town of Bar' (N. Duner 1912: 19)

It also frequently appears at the beginning of an independent sentence or clause:

- And the tax-collector ran to see what was going on there, and there she was, lying like a dead person' (Rodkinsohn 1865: 8)

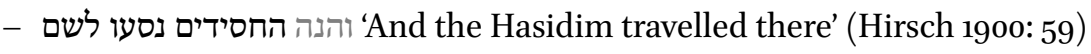

- והנה פתאום התחילו הסוסים לרוץ עם העגלה 'And suddenly the horses started to run with the wagon' (Moses Leib of Sasov 1903: 21a)

- And that rich man was also a scholar' (Michelsohn 1910c: 54 )

It occasionally appears directly following a temporal clause, e.g.:

- ובשובה אליו. והנה הרבי אינו בבית 'And when she returned to him, the Rebbe was not in the house' (Teomim Fraenkel 1911a: 49)

- ויהי בבואם חוץ לעיר והנה מרחוק נסעו הבעלי עגלות הנ"ל 'And when they came to the outskirts of the city, [they saw that] from afar those wagon-drivers were travelling' (M. Walden 1912: 18)

As mentioned above, it sometimes appears in direct speech with past tense reference, e.g.: 
- ואקום בבוקר והנה כל הרגל נתנפח 'And I got up in the morning and saw that the whole leg had swollen up' (Teomim Fraenkel 1910: $5^{8}$ )

Rarely, הנה appears in a past tense narrative setting without the conjunction waw, e.g.:

- ויחשוב דרכו מה הוא עושה הנה הוא נוסע לצדיק כזה ומוליך אהובות זונות And he thought on his way [about] what he was doing; for here he was, going to such a righteous man and bringing lovers, prostitutes' (Rodkinsohn 1865: 45)

This Hasidic Hebrew usage mirrors to a considerable extent that of the biblical particle וְִּּנִ, which has been interpreted to convey vividness or immediacy (see e.g. van der Merwe 2007) and can be followed by a qoțel or qațal as well as other verbal and non-verbal forms (Zewi 1996: 34). However, there seems to be a difference between the biblical and Hasidic uses of the particle. The biblical וְ וִהֵֶּה typically appears following verbs of sight, descriptions of dreams and visions, or other sight- or motion-related contexts (Zewi 1996: 27-28). By contrast, while the particle in Hasidic Hebrew often follows the verb ר.א. 'see', it does not necessarily follow explicit or implied verbs of sight or motion; indeed, as illustrated above, it frequently appears at the beginning of new sentences and narrative portions that are not directly connected to the preceding passage. Moreover, והנה immediately following a temporal clause without an introductory particle הנה wa ויה wathout the prefixed conjunction waw in narrative are not typical features of Biblical Hebrew.

It is likely that the partial resemblance in usage between Biblical and Hasidic Hebrew in this respect is attributable to the fact that the authors were intimately familiar with the biblical text and so incorporated the particle into their own writing in contexts that they perceived to resemble those of their biblical model. As in many other aspects of Hasidic Hebrew grammar, this tendency may be rooted in a desire to situate the tales linguistically within the venerable tradition of biblical narrative. However, the fact that (1) was not used in post-Biblical Hebrew and lacks an equivalent in their vernacular most likely meant that they did not fully understand the range of syntactic and semantic nuances of the biblical particle (which is not remarkable, given that it remains a subject of debate among present-day grammarians), and consequently employed it in somewhat different positions than those of the Hebrew Bible. 


\subsubsection{Preceding Infinitive Construct}

The particle הנה with pronominal suffixes can be placed before an infinitive construct in order to convey the sense that the subject is about to perform the action indicated by the infinitive construct. In many cases there seems to be an element of willingness on the part of the subject to carry out the action conveyed by the infinitive. This usage is illustrated in the following examples:

- And I am about to copy down that which is relevant to our matter here' (Rodkinsohn 1864b: 38 )

- ע"כ הנני להודיעך את אשר יעצו עליכם הכומרים 'Therefore I am going to inform you what the priests have advised against you' (Shenkel 1903b: 24)

- הנני לערוך לפניכם שולחן ערוך בשר לאכול 'I am going to set a table before you laid with meat to eat' (Ehrmann 1903:14b)

- מעתה הנני לקיים ככל אשר תשית עלי 'From now on I am going to carry out everything that you impose on me' (Bodek 1865c: 4)

- הנני לעשות רצון הבורא 'I am going to do the will of the Creator' (Singer 19oob: 22)

- הנני להעתיק דבר נחמד 'I am going to copy down a pleasant matter' (Chikernik 1903b: 32 )

This usage is noteworthy because it seems to lack precedent in earlier forms of Hebrew. In Biblical Hebrew the particle הנה is often found preceding a qoțel with imminent future force (Waltke and O'Connor 1990: 627), but is never attested in conjunction with an infinitive construct. Similarly, the infinitive construct prefixed by can itself serve to denote an imminent action (Waltke and O'Connor 1990:610), but this use does not occur following הנה. Conversely, in Rabbinic Hebrew the particle הנה is not a productive feature, having been replaced by הרי (Pérez Fernández 1999: 20, 173), and the latter is not used in conjunction with an infinitive construct to indicate imminent action. Moreover, this construction does not seem to appear in Medieval Hebrew literature. However, the same phenomenon is widely attested in Maskilic Hebrew literature (see Kahn 2009: 277-279 for details of this convention). This is one of many examples of the high degree of linguistic similarity between Hasidic and Maskilic Hebrew narrative. In addition, the construction appears in some eighteenth- to early twentieth-century Ashkenazi responsa, e.g. Moses Sofer's eighteenth/nineteenth-century Hatam Sofer and Moses Nahum Yerushalmiski's Be'er Moshe (1901). This suggests that the construction can be regarded as a more widespread Eastern European Hebrew phenomenon. 
12.5 שי

The particle יש is widely attested in Hasidic Hebrew and typically functions as an existential particle with an indefinite noun with a translation value of 'there is/there are', as below. This mirrors the standard function of the particle in Biblical and post-Biblical Hebrew (see e.g. Gibson 1994: 56-57; Azar 1995: 85; Rabin 2000: 109-110; Rand 2006: 398).

- יש לי ידיעה ברורה אשר הדבר עומד במצב טוב 'I have clear knowledge that the matter is in a good condition' (Bromberg 1899:30)

- יש אנשים ששואלים עלי במה אני גוטער יוד 'There are people who ask me in what way I am a Hasidic rebbe' (J. Duner 1899: 39)

- 'There is a God in Israel' (Rodkinsohn 1864a: 12)

In conjunction with a suffixed form of the preposition $-ל$, it serves to indicate possession in a manner equivalent to the English verb 'have', e.g.:

- כל כספך אשר יש לך 'all your money that you have' (A. Walden 186o?: 31a)

- אמר החתן לחביריו שהכלה יש לה פנים כמו נכרית כ'The groom said to his friends that the bride had a face like a non-Jewish girl' (Michelsohn 1905: 65)

- איש אחד יש לו דין ודברים עמכם 'There is a man who has an issue with you' (Teomim Fraenkel 1911b: 5)

\section{נא 12.6}

The particle נא is a common feature of the Hasidic Hebrew tales. The authors' employment of נא is most likely modelled on its appearance in the Hebrew Bible, wherein it is a common and characteristic feature, in contrast to Rabbinic Hebrew, in which it is relatively marginal and restricted to biblicizing liturgical and poetic settings (Segal 1927: 148).

\subsubsection{Syntactic Properties}

In Hasidic Hebrew נא appears frequently in direct speech in conjunction with a variety of verbal forms. It most commonly appears directly following an imperative, e.g.:

- קום נא ובא אחרי אל הרב כי קורא אליך 'Please get up and follow me to the rabbi, because he is calling for you' (Bodek 1865 b: 28 )

- שמע נא מה שהמלמד אומר עליך'Please listen to what the teacher is saying about you' (Zak 1912: 8) 
- לך נא לחוץ 'Please go outside’ (Rodkinsohn 1864b: 16)

- חמול נא על נפשי 'Please have mercy on my soul' (Hirsch 1900:43)

It may also follow third person yiqtol forms with command force, as below:

- ילך נא עתה לנוח 'Let him now go to rest' (Bodek 1865a: 48)

- ידבר נא ל- 'Let him speak' (Laufbahn 1914:46)

- יגיד נא לנו רבינו 'Let our rabbi please tell us' (Rodkinsohn 1865:1)

- יהיה נא מטובכם לגלות לי האמת לג' 'Please be so kind (lit: let it please be of your goodness) to reveal the truth to me' (Rodkinsohn 1865:13)

- תיקר נא נפש עבדך בעיני אדוני (May the life of your servant be valued in your eyes, my lord' (Kaidaner 1875: 10b)

- הנה יכירו נא אותי 'Here, let them get to know me' (Landau 1892: 62)

Although the syntactic properties of the Hasidic Hebrew נא resemble those of its biblical counterpart, there is a slight difference between the biblical and Hasidic employment of the particle in conjunction with third person commands of hifil, III-Th, and hollow roots: in such cases Biblical Hebrew employs a distinct shortened jussive form, while Hasidic Hebrew, in which the jussive is not a productive feature (see 8.7.3), uses the yiqtol instead.

More rarely, נא may follow first person yiqtol, e.g.:

- אלביש נא את מלבושי 'Please let me put on my clothes' (Rodkinsohn 1864a: 10)

- נדבר נא איזה פלפול מחידושי תורה 'Let us have (lit: speak) a debate about Torah interpretations' (J. Duner 1899: 41)

- אבוא נא בבקשה לפני מעלתו 'Let me come before his honour with a request' (Michelsohn 1912: 93)

- אולי אנסה נא ג"כ ליסע אליו 'Maybe I will also try to travel to him' (Yellin 1913: 26)

Usually nothing separates the verb from the following נא. The example below is a rare exception, whereby a suffixed preposition intercedes between the verb and the particle. This usage does not seem to have biblical precedent, which may point to a somewhat different understanding of the particle's syntactic properties on the part of the Hasidic Hebrew authors, possibly influenced by their native Yiddish (see directly below for details).

- יגיד לי נא 'Let him tell me' (Berger 1907:53)

also appears relatively frequently preceding its associated verb, e.g.: 
- הוא נא יסעוד 'Let him dine' (Ehrmann 1911: 23b)

- נא יספרם 'Let him tell them' (Rosenthal 1909:17)

- נא אל תכחד 'Please do not deny' (Rakats 1912, pt. 1:15)

- יותר אין לכם לספר. נא תסעו לחיים ולשלום 'You don't have anything more to tell. Please go away in good health (lit: to life and to peace)' (Munk 1898: 21)

- ויאמר להאורח נא צייר לי בדבריך תארה 'And he said to the guest, "Please describe her with your words"' (Rodkinsohn 1865:40)

This position is noteworthy as it seems to be without precedent in earlier forms of Hebrew. In Biblical Hebrew נא invariably placed after the associated verb (Gesenius-Kautzsch 1910: 308), and the infrequent attestations of the particle in rabbinic literature reflect this convention, as do other post-biblical forms of the Hebrew such as the language of Palestinian piyyuțim (Rand 2006: 399). The Hasidic Hebrew fronting of the particle may be due to influence from Yiddish: if, as is likely, the authors interpreted נא as a politeness particle (see following ביטע section), they may have equated it with the Yiddish politeness marker 'please', which commonly precedes its associated verb, leading them to treat it similarly.

\subsubsection{Semantic Function}

The semantic significance of the Hasidic Hebrew נא is not completely certain. The contexts in which it appears generally suggest that it is a politeness marker with a translation value of 'please', as illustrated in the English translations of the examples below. However, it is not entirely clear that the authors employed it with such a meaning in mind.

- שאל נא לאשתך כמה היא צריכה בכל שבוע 'Please ask your wife how much she needs every week' (Chikernik 1903a: 14)

- נא תנו לי דבר מה 'Please give me something' (Rosenthal 1909: 74)

- ספר נא עתה את הדיבורים אשר דברת 'Please tell me now these things that you have said' (Michelsohn 1910a: 38)

This uncertainty is rooted to an extent in the fact that the function of $\mathrm{N}$ in the Hebrew Bible is somewhat unclear and grammarians have interpreted it in various ways, e.g. as a marker of logical consequence (see Lambdin 1971: 170-171; Waltke and O'Connor 1990: 578-579; Fassberg 1994: 70-71), as a particle of entreaty (Joüon-Muraoka 2006: 322-323), and as lacking any semantic significance (Arnold and Choi 2003: 65), in addition to as a politeness marker (Kaufman 1991; Shulman 1999). However, the rabbis of the Talmud understood the biblical particle to be a politeness marker (see Kaufman 1991: 195), and as 
the Hasidic authors would most likely have been familiar with this rabbinic explanation it is plausible that they interpreted and used נא as a politeness marker themselves. Alternatively, however, it is possible that they used it without attaching any particular semantic significance to it, simply because it was familiar to them from its frequent appearance in the Hebrew Bible.

\subsection{Directive ה-}

The directive suffix ה-is a common and widespread feature of Hasidic Hebrew. It is frequently attested on a range of nouns deriving from Biblical Hebrew, as shown below. Most of these forms occur frequently in the biblical corpus, but some of them are relatively rare; for example, הפתחה 'to the door' appears only once (in Genesis 19:6). These rarer biblical forms nevertheless appear in well-known narratives and were therefore most likely very familiar to the authors.

- אנה ואנה 'here and there' (Rodkinsohn 1865:38)

- ארצה 'to the ground' (Laufbahn 1914:47)

- הביתה 'homewards' (Rakats 1912, pt. 1: 53)

- החדרה 'into the room' (Kamelhar 1909:31)

- 'towards outside' (Jacob Isaac ben Asher of Przysucha 1908:47)

- העירה 'to the city' (Baruch of Medzhybizh 1880: 27)

- הפתחה 'to the door' (Singer 1900a, pt. 3:5)

- השמימה 'heavenwards' (Shalom of Koidanov 1882: 21)

- חוצה 'towards outside' (Ehrmann 1903: 4a)

- פלוזה 'to Luz'4 (Sobelman 1909/10, pts. 1-2: 37)

- פנימה '(towards) inside' (Michelsohn 1910a:118)

- שדימה 'forwards' (Zak 1912: 14)

- שאולה 'to Sheol' (Bodek 1865c: 8)

- שמה '(to) there' (Teomim Fraenkel 1911b: 10)

Strikingly, the directive suffix in Hasidic Hebrew is not restricted to these forms with biblical precedent. Rather, it is frequently used innovatively with Eastern European place names, as below. These forms seem to lack clear precedent in earlier Hebrew texts. The most popular of these forms is לובלינה 'to Lublin', shown in the first example below, which is attested many times in the work of

4 Earlier name for the biblical city of Bethel, mentioned in Gen. 28:19 and 35:6. 
seven different authors. Michelsohn's use of the directive suffix in such cases is particularly productive, as illustrated in the following examples.

- אמשטרדמה 'to Amsterdam' (Michelsohn 1912: 91)

- לבובה 'to Lvov' (Michelsohn 1912: 92)

- לובלינה 'to Lublin' (Teomim Fraenkel 1911a: 35)

- ליזענסקה 'to Lizhensk' (N. Duner 1912: 25)

- פעטערבורגה 'to St. Petersburg' (Breitstein 1914: 26)

- רומנובה 'to Romanov' (Michelsohn 1910c: 13)

This appears exceptionally with a tautologous prefixed preposition as well, as follows:

- ללובלינה 'to Lublin' (Ehrmann 1911: 27b)

The adverb שמה '(to) there' is often used with a locative rather than directive force, as shown below. This usage has precedent in Biblical Hebrew (EvenShoshan 2003: 1912).

- הוא שאל [...] אם יכתוב לאנשי ביתו שיסעו משמה לקאזניץ He asked [...] if he would write to the members of his house so that they would travel from there to Kozienice' (Bromberg 1899: 18)

- והנאמן ישב שמה כמעט כל השנה 'And the loyal man stayed there almost the whole year' (Seuss 1890: 10)

The same locative sense is also once found with another noun, shown below. This latter usage does not seem to have clear precedent in Biblical Hebrew, in which the locative $ה$ - is attested only with place names prefixed by the אצל inseparable preposition ' 'in' or preceded by the independent preposition 'near'; 'next to' (Williams 2007: 26).

- נתהוה אש מתלקחת גדולה תוך העירה 'a great consuming fire started inside the city' (Ehrmann 1903: 1b)

The directive suffix can sometimes be used without the definite article and a following place name, as below. This usage does not seem to be attested in earlier canonical Hebrew writings.

- עירה מעזיבוז 'to the town of Medzhybizh' (Bodek 1865b: 3)

- עירה ווין 'to the city of Vienna' (M. Walden 1912: 109) 


\section{ה Interrogative}

The prefix ה-, which serves to form polar questions, is a relatively common feature of Hasidic Hebrew, as shown below. Interrogative is attested in both Biblical and Rabbinic Hebrew. However, it is a common element of Biblical Hebrew (Williams 2007:192) but is relatively rare in rabbinic literature (Segal 1927:220); therefore, its somewhat more frequent attestation in Hasidic Hebrew may indicate that in this case the authors were drawing primarily on their familiarity with the form from biblical texts. As in many other cases discussed throughout this volume, it is possible that the authors employed this form because they associated it with biblical literature and wanted (perhaps subconsciously) to root their own writing within the linguistic and literary tradition of biblical historical narrative.

- המכיר אתה את הרב מסטאלין 'Do you know the rabbi from Stolin?' (Rodkinsohn 1864b: 16)

- הידעת מה היום 'Do you know what day it is?' (Landau 1892:14)

- והתחיל הרוח לבכות אמר הלהרגני אתה אומר מה 'And the ghost started to cry; he said, “Do you seek to kill me?"' (Kaidaner 1875: 24a)

- הזוכר אתה עת שהיינו שנינו חברים 'Do you remember the time when we two were friends?' (Gemen 1914: 69)

- "הנשאר לך עדיין איזה קושיא, 'Do you still have any questions?' (N. Duner 1912: 27)

- הזאת למדת ממני 'Did you learn this from me?' (Jacob Isaac ben Asher of Przysucha 1908: 50)

- שאלו הידעת את מענדיל 'They asked, "Do you know Mendl?"' (Michelsohn 1910c: 70$)$

- התכיר את המלמד בעירך 'Do you know the melamed in your town?' (Seuss 1890: 15)

- האכלת מה היום 'Have you eaten anything today?' (Breitstein 1914: 33)

- היוכל להיות שהרבי זצלה"ה אינו יודע שהוא בעל עבירה 'Can it be that the Rebbe of everlasting memory doesn't know that he is a sinner?' (M. Walden 1913, pt. 3: 8)

In addition, the particle frequently appears in the construction הלא 'is it not the case', introducing a question for which a positive reply is expected, e.g.:

- 'Isn't there a young woman here?' (Bromberg 1899: 25-26)

- הלא אתה אינו שוטה 'Of course, you're not a fool' (Munk 1898: 65) 
- הלא אנכי התפללתי אצליכם 'Didn't I pray with you?' (Laufbahn 1914:50)

- הלא יש לי חבירים אציכם -Don't I have friends?' (Sofer 1904:7)

Similarly, it is used in the formation of the independent interrogative האם, which, like the prefix, serves to introduce polar questions, e.g.:

- האם חזרת אליו האופן 'Did you return the wheel to him?' (Bromberg 1899:32)

- האם למד? 'Did he study?' (Ehrmann 1911: 10b)

- האם הבאת את זה 'Did you bring this?' (Bodek 1865c: 7)

- האם אתה הבאת החבילה ז'Did you bring the package?' (HaLevi 1909:53)

\subsection{Interjections}

The Hasidic Hebrew authors express the interjection 'yes' by means of הן, as below. This usage is likely to derive primarily from Rabbinic Hebrew, in which the particle may be employed in the same sense (Jastrow 1903: 356; Pérez Fernández 1999:172). הן is likewise attested in Biblical Hebrew, but differs from its Hasidic counterpart in that it is not an interjection but rather a clitic serving to introduce another constituent (Garr 2004: 324); moreover, it does not simply convey assent but instead is used to present facts or shared knowledge and to signal a range of epistemic values including speaker conviction, commitment, and certainty (see Garr 2004 for details). Nevertheless, the fact that the various biblical uses all have an affirmative sense may have reinforced the Hasidic Hebrew usage despite any syntactic and semantic differences.

- ושאלם הלובלינר הראיתם אותו. ואמרו הן 'And the Lubliner Rebbe asked them, "Have you seen him?" And they said, "Yes"' (Landau 1892: 6)

- והליטוואק חשב שלא שמע הרב מה היה השיב לו והשיב לו הן 'And the Lithuanian Jew thought that the Rebbe had not heard what he had answered him, and he answered him, "Yes"' (Munk 1898: 23)

- ואמר לו אם רוצה אתה להיות לי מלצר ואמר הן 'And he said to him, "Do you want to be my attendant?" And he said, "Yes"' (Shenkel 1903b: 12)

- ונענה לו הרה"ק בראשו, הן, יודע אני "And the holy Rebbe answered him with his head, "Yes, I know"' (Breitstein 1914:12) 